
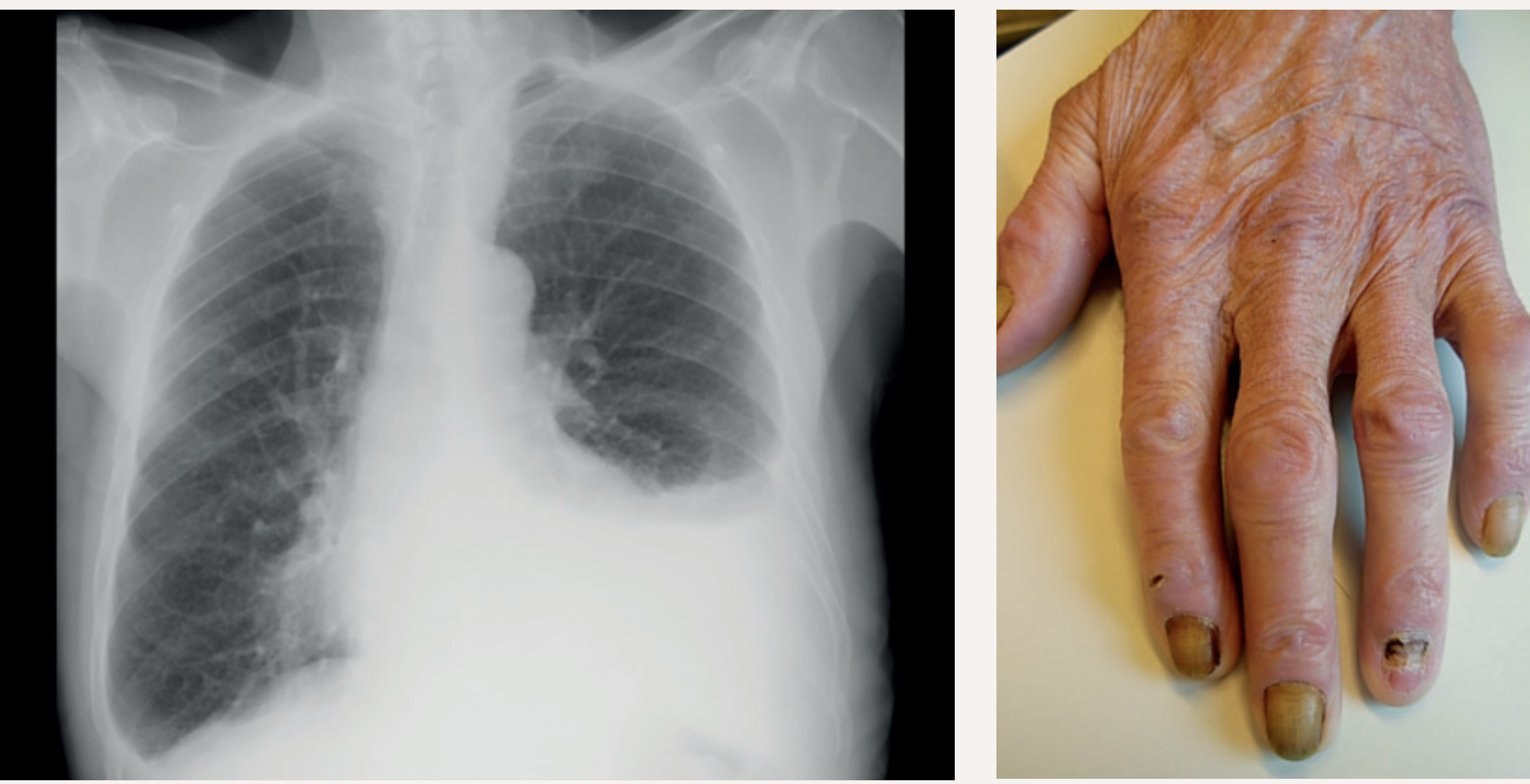

Foto Martin Petersen

\title{
Gule negler-syndromet
}

En 80 år gammel mann med kjent røykeutløst kronisk obstruktiv lungesykdom ble innlagt med raskt atrieflimmer, bilaterale ankelødemer og dyspné. Røntgen thorax viste bilateral pleuravæske, mest uttalt på venstre side som initialt ble antatt å være sviktbetinget, men som viste seg å være eksudat. Utredningen ga ingen holdepunkter for infeksjon, lungeemboli, bindevevssykdom, medikamentbivirkning eller malignitet. Ved fornyet klinisk undersøkelse oppdaget man påfallende forandringer på alle fingerneglene.

Gule negler-syndrom (yellow nail syndrome) er en sjelden tilstand med triaden gule negler, lymfødem og respiratoriske symptomer som kan skyldes pleuravæske, bronkiektasier eller sinusitt. Det mest karakteristiske er negleforandringene. Fargen er gul eller gulgrønn, eventuelt begrenset til neglens distale halvpart. Neglene er fortykkede og dyskeratotiske og har tapt den halvmåneformede lunulaen. Det er økt krumning av neglen både på langs og på tvers. Onykolyse kan forekomme. Neglens veksthastighet er betydelig nedsatt, og det er sjelden behov for negleklipping. Oftest er negleforandringene det første symptomet på syndromet, mens pleuravæsken oppstår sist.

Man antar at tilstanden skyldes en ervervet dysfunksjon i lymfesystemet, men dette er omdiskutert. Behandlingen er symptomatisk, og først og fremst rettet mot de respiratoriske symptomene. Det finnes ingen spesifikk behandling mot negleforandringene, men de kan bedres dersom man får kontroll over de respiratoriske symptomene. Vår pasient ble behandlet med gjentatte pleuratappinger og pleurodese.
Pasienten har gitt tillatelse til at artikkelen blir publisert.

\section{Oppgitte interessekonflikter: Ingen}

\section{Martin Petersen*}

martinpe@hotmail.com

Medisinsk avdeling

Molde sjukehus

6412 Molde

* Nåværende adresse:

Lungeavdelingen

Haukeland universitetssykehus

5021 Bergen

Manuskriptet ble mottatt 13.8. 2009 og godkjent 27.11. 2009. Medisinsk redaktør Michael Bretthauer. 